\title{
Cianobaktériumok és eukarióta algák talajszuszpenzióból történő közvetlen vizsgálatának lehetősége áramlási citométerrel
}

\author{
${ }^{1}$ Lepossa Anita, ${ }^{1}$ Hoffmann Sándor és ${ }^{2}$ NAGY Szabolcs \\ ${ }^{1}$ Pannon Egyetem Georgikon Kar, Növénytermesztéstani és Talajtani Tanszék és \\ ²́llattudományi és Állattenyésztéstani Tanszék, Keszthely
}

\section{Bevezetés}

Hazánkban a talajalgákkal foglalkozó kutatások a múlt század első felében indultak Fehér Dániel (FEHÉR, 1936; FEHÉR \& FRANK, 1936) fóként erdei talajok algatartalmának és a talajalgák fényigényével kapcsolatos vizsgálataival, majd Kiss István az időjárási tényezők talajalgákra gyakorolt hatásainak értékelésével (KISS, 1968) és P. Komáromy Zsuzsanna nemzetközileg is nagy jelentőségü talaj algaflóra kutatásaival (KOMÁromy, 1976, 1983, 1985).

A talajok algaközössége számos abiotikus környezeti tényezó és biotikus kölcsönhatás bonyolult összjátéka szerint müködik, melynek szabályai még ma sem tisztázottak kellőképpen. A talajok algaközösségét befolyásoló legfontosabb tényezők az életmód, a fény, a nedvesség, a hőmérséklet, a pH és a felvehető tápanyagtartalom (LEPOSSA, 2002). Hazai talajokra vonatkozóan kvantitatív algológiai vizsgálati eredményekről mindössze két forrás ad számot (FEHÉR, 1936; LEPOSSA \& ÖRDÖG, 2006). Nemzetközi viszonylatban is meglehetősen kevés adat áll rendelkezésre, amelyek az alkalmazott módszerek sokfélesége miatt is nehezen összevethetők. A talajalgák kvantitatív értékelésére - hasonlóan a mikroszkopikus gombák és baktériumok vizsgálataihoz - indirekt és direkt sejtszámlálási módszerek állnak rendelkezésre. A közvetett sejtszámlálási módszerek közül a hígított tenyészetek módszere és az MPN-módszer eszköz-, idő- és munkaigényességükön túl azt a hibát is magukban hordozzák, hogy a tápközeg összetétele és a tenyésztési körülmények hatására egyes fajok kiszorulnak, míg mások uralkodóvá válhatnak, torzítva a számlálás eredményét. A klorofill-a extrakciós módszer azt veszi alapul, hogy mind az eukarióta algák, mind a prokarióta cianobaktériumok sejtjei tartalmaznak aklorofillt. Bár a módszer maga egyszerü és gyors, használatával durva becslést kapunk csupán, és a módszer nem teszi lehetővé az egyes taxonok elkülönített mérését. Ráadásul a talaj klorofill-a tartalmú növénymaradványai is befolyásolják az eredményt.

Postai cím: LEPOSSA ANITA, Pannon Egyetem, Georgikon Kar, 8360 Keszthely, Deák F.

u. 16. E-mail: Lepossaa@georgikon.hu 
A közvetlen sejtszámlálási módszerek közé tartozó vizes talajszuszpenzióból történő fénymikroszkópos számlálásnál az algasejteket még 400-szoros nagyítás mellett is meglehetősen nehéz, gyakran lehetetlen elkülöníteni a talajszemcséktől és a szuszpenzió egyéb elemeitől.

Az előző módszerekhez viszonyítva a klorofill-a autofluoreszcencián alapuló mikroszkópos sejtszámlálás lényegesen gyorsabb és nagyobb pontosságú. A módszer azon alapul, hogy az algasejtek klorofilltartalma megfelelö hullámhosszúságú gerjesztő fény hatására vörös színt emittál, mely révén azok könnyen észrevehetők a sötét háttérben, és jól elkülönülnek a nem gerjesztődő, vagy gerjesztve más színt emittáló ásványi anyagoktól és szerves törmeléktől. A fluoreszkáló sejtek jól kirajzolódó körvonala az egyes taxonok könnyü felismerését, a fonalak és kolóniák sejtszám-becslését is lehetővé teszi. A módszer talán egyetlen hátránya, hogy a vizsgálatot végző szemét erősen igénybe veszi, de azt is meg kell említeni, hogy a módszerrel csak a méréskor aktív anyagcseréjü sejtek értékelhetők (TSUJIMURA et al., 2000).

A fluoreszcens jelek detektálásának évtizedek óta ismert automatizált, nagy sebességü eszköze az áramlási citometria, amelyet ma már széles körben alkalmaznak. Az automatizált sejtértékelés és számlálás citométerrel nagyságrendekkel gyorsabb és precízebb a mikroszkópos módszerekkel összehasonlítva (SHAPIRO, 1995; ROBINSON et al., 1997; VEAL et al., 2000). A hidrobiológusok is régóta sikerrel alkalmazzák algológiai vizsgálatokhoz (OLSON et al., 1985). Ennek során az egyes taxonok (eukarióta algák, ill. cianobaktériumok) jól elkülöníthetők az eltérő pigmenttartalomnak köszönhető jellegzetes autofluoreszcenciájuk alapján: a klorofill-a vöröses színe eltér a csak a cianobaktériumokra jellemző fikoeritrintől, amely inkább narancssárga színnel fluoreszkál (GIVAN, 2001). Ez az analitikai módszer tette lehetővé új algataxonok, pl. az óceánok és tengerek pikoalgáinak felfedezését is (CHRISHOLM et al., 1988), talajbiológiai alkalmazása még csak a kezdeteknél tart.

A talajminták mikrobiológiai elemzése során napjainkig jellemzően föleg a baktériumok vizsgálatára koncentráltak, DNS-festékek alkalmazásával (RESINAPELFORT et al., 2003). Az algasejtek autofluoreszcens jeleik alapján a talaj vizes szuszpenziójában közvetlenül is detektálhatók, áramlási citométerrel.

LENTENDU és munkatársai (2013) ezt az analitikai megközelítést alkalmazta talajok egysejtủ eukarióta algaflórájának és mikroszkopikus gombaflórájának elemzésére. A két sejtcsoportot a klorofill-a autofluoreszcencia intenzitása alapján különítették el. Megközelítésük elvileg tovább bővíthető a cianobaktériumok autofluoreszcens pigmentjeinek egyidejü detektálásával. A talajszuszpenziók vizsgálatán alapuló automatizált módszer kidolgozása nagy elörelépést jelentene a talaj fotoszintetizáló mikroszervezeteinek közvetlen detektálásában és az algák talajökoszisztémában betöltött szerepének jobb megismerésében.

Jelen előkísérletünkben Ramann-féle barna erdőtalajon, négy növénykultúrából (őszi búza, bíborhere, kukorica és szója) gyüjtött talajminták cianobaktérium- és eukarióta mikroalga sejtszám meghatározását végeztük el. Célunk az áramlási citometria alkalmazhatóságának, technikai korlátainak megismerése volt, továbbá előzetes eredményeket kívántunk gyüjteni későbbi, nagyobb volumenủ algológiai vizsgálatok kísérlettervezésének hatékonyabbá tétele érdekében. 


\section{Anyag és módszer}

\section{Mintagyüjtés és -előkészités}

Keszthelyen, a Pannon Egyetem Georgikon Kar kísérleti területén (É: 46,74, K: $14,24^{\circ}$ ) négy növénykultúra, öszi búza (Triticum aestivum, „Mulan”), bíborhere (Trifolium incarnatum, „Lovászpatonai”), kukorica (Zea mays, „P9175”) és szója (Glycine max, „Aires”) kezeletlen parcelláinak 0-5 cm-es talajrétegből 2013 júliusában talajmintát vettünk hat ismétlésben; mindegyik minta három leszúrásból származott.

A talaj típusa Ramann-féle barna erdőtalaj, homokos vályog fizikai féleségü felső müvelt réteggel ( $21 \%$ agyagtartalom, 0,87\% szervesszén-tartalom). A müanyag tasakokba gyüjtött mintákat a laboratóriumba érkezést követően alaposan átkevertük, majd mértük a minták nedvességtartalmát és desztillált vizes pH-ját.

A citométeres vizsgálatokhoz bemért $10 \mathrm{~g}$ friss talajt $250 \mathrm{ml}$ térfogatú, alufóliával lezárt lombikban egy éjszakán át sötétben, hütve $\left(4^{\circ} \mathrm{C}\right)$ tároltuk. Másnap a mintákból $10 \mathrm{~g}$ friss talaj/ $100 \mathrm{ml}$ desztillált víz koncentrációjú szuszpenziót készítettünk, melyet ultrahangos kádban homogenizáltunk $(50 \mathrm{~Hz}, 280 \mathrm{sec}$.) és alapos átkeverés után, fél perc ülepedési időt követően a felszín alól kivett kb. $900 \mu \mathrm{l}$ szuszpenziót $30 \mu \mathrm{m}$-es szürőn (Partec CellTrics) szürtük át. Ezt követően a szürlet aktív algasejt-tartalmát áramlási citométerrel mértük.

\section{Áramlási citometria}

A mérésekhez Beckman Coulter FC-500 citométert használtunk (szoftver: FC500 CXP), mintánként öt perc futtatási idővel, "LOW" $\left(10 \mu \mathrm{L} \cdot\right.$ perc $\left.^{-1}\right)$ mintaáramlási sebességgel. A gerjesztéshez $488 \mathrm{~nm}$ hullámhosszúságú Ar ion $(20 \mathrm{mV})$ lézert alkalmaztunk.

A fikoeritrin jelét az FL 2 (575 nm BP), a klorofill-a jelét pedig az FL 4 (675 nm BP) fluoreszcens detektorokkal lineáris módban rögzítettük. A szürletben található talajszemcsék, törmelék stb. és az aktív algasejtek megkülönböztetésére a klorofill-a autofluoreszcencia szignált alkalmaztuk diszkrimináló paraméterként, így csak azokat az eseményeket rögzítettük, amelyek pozitív klorofill-a autofluoreszcenciát mutattak.

\section{Adatelemzés}

Az LMD formátumban tárolt adatfájlokat Flowing 2.5.1. (www.flowing.com) ingyenes szoftverrel elemeztük.

Az eredményeket nemparaméteres Kruskal-Wallis ANOVA és post hoc MannWhitney U-próbával értékeltük, Statistica for Windows 8.0 szoftverrel.

A müszer által az öt perc futtatási idő alatt rögzített eseményszámból következtettünk a talaj nedvességtartalmával korrigált alga sejtszám-értékeire. 


\section{Eredmények}

A felszíni öt centiméteres rétegből gyüjtött talajminták nedvességtartalma kukorica, búza és a szója kultúrákban $6,3 \pm 1,1 ; 5,1 \pm 0,6$ és $5,5 \pm 0,6 \mathrm{~m} / \mathrm{m} \%$ volt, a legnagyobb nedvességtartalmat $(10,1 \pm 1,7 \mathrm{~m} / \mathrm{m} \%$-ot) a bíborhere talaja mutatott (átlag \pm szórás). A friss talajminták vizes oldata a kukorica és a szója talajában lúgos $(\mathrm{pH}=8,6 \pm 0,02$, ill. 8,6 $\pm 0,05)$, a búza talajában $(\mathrm{pH}=7,4 \pm 0,02)$ semleges, a bíborhere talajában $(\mathrm{pH}=6,7 \pm 0,14)$ gyengén savanyú kémhatást adott (átlag \pm szórás).
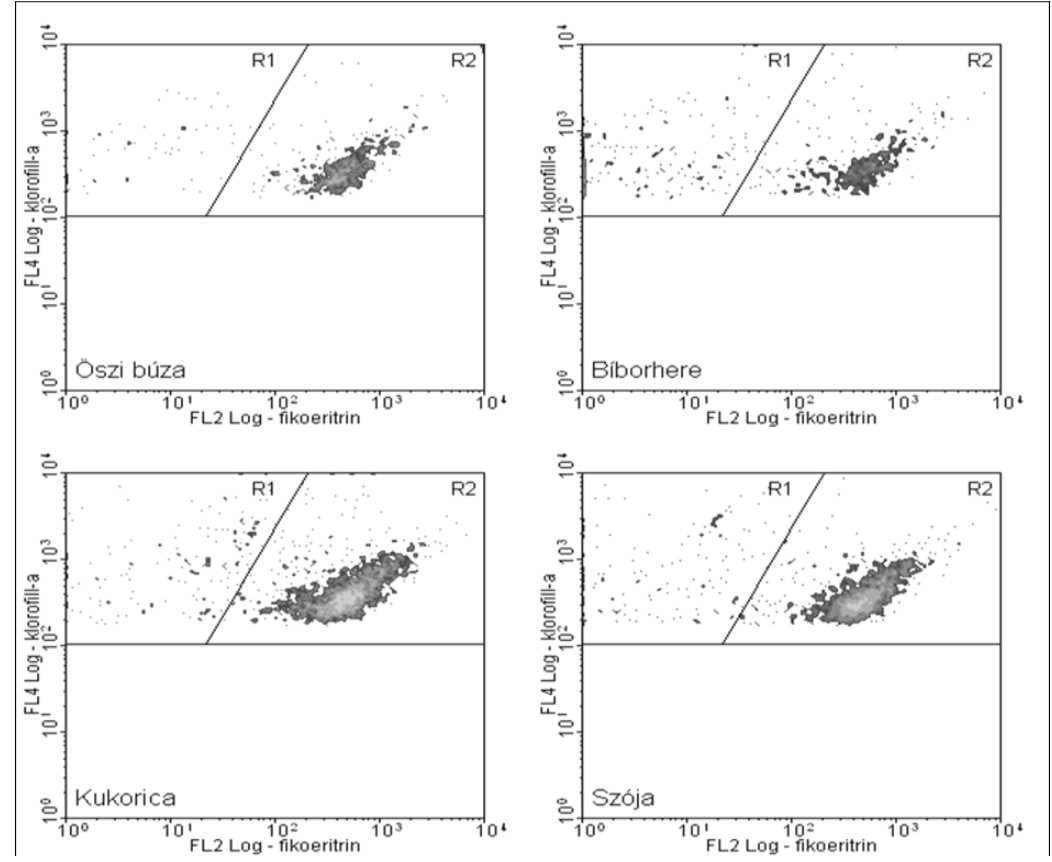

1. ábra

Az eukarióta alga (R1) és a cianobaktérium (R2) sejtcsoportok megjelenése a klorofill-a és a fikoeritrin autofluoreszcencia intenzitás értékek alapján az őszi búza, bíborhere, kukorica és szója talajának vizes szuszpenziójában

A citométeres ábrákon - megfelelő beállítások után - jól elkülönülő sejtpopulációk jelentek meg (1. ábra).

A kétdimenziós citogramokon az eukarióta algák magas klorofill-a és alacsony fikoeritrin autofluoreszcenciát mutattak (R1 régió). A cianobaktériumok magas fikoeritrin autofluoreszcenciával (FL2 az x-tengelyen), és magas klorofill-a autofluoreszcenciával (FL4 az y-tengelyen) jelentek meg.

A müszer által rögzített eseményeket elemezve - a prokarióta-eukarióta arányt tekintve - valamennyi mintában a cianobaktériumok domináltak. A kukorica és a szója talajában legalább $80 \%$-os jelenléttel és a másik két kultúra talajában is 60 70\%-os aránnyal (2. ábra). 


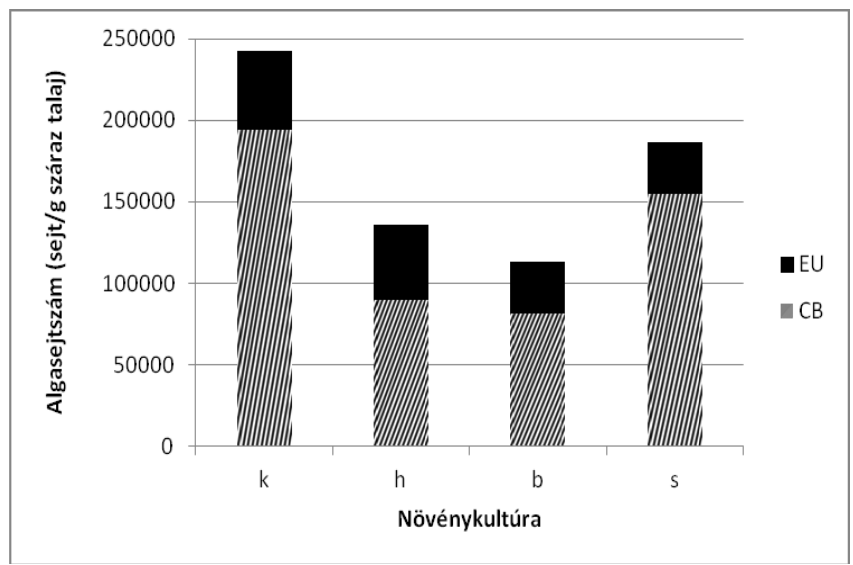

2. ábra

A becsült átlagos összes algasejtszám, illetve a prokarióta $(\mathrm{CB})$ és az eukarióta $(\mathrm{EU})$ alga sejtszám-arány a kukorica (k), a bíborhere (h), az öszi búza (b) és a szója (s) vizsgált $0-5 \mathrm{~cm}$-es talajrétegében (Keszthely, $2013(\mathrm{n}=6)$ )

Összességében is a kukorica és a szója talajában detektáltuk a legnagyobb alga jelenlétet $\left(2,4 \cdot 10^{5}\right.$ ill. $1,9 \cdot 10^{5} \mathrm{sejt} \cdot \mathrm{g}^{-1}$ száraz talaj). A búza talajában pedig a legkevesebbet, alig $50 \%$-ot a kukorica talajához viszonyítva $\left(1,1 \cdot 10^{5} \mathrm{sejt} \cdot \mathrm{g}^{-1}\right.$ száraz talaj).

A cianobaktériumok becsült sejtszámát tekintve a kukorica és a szója talajában jelentősen $(p<0,05)$ nagyobb abundancia mutatkozott a bíborhere és az öszi búza talajához viszonyítva (3A. ábra).

A kukorica- és szója talajának becsült eukarióta algasejtszáma közötti különbség szignifikáns ( $\mathrm{p}<0,05)$ - a kukorica javára (3B. ábra).

A

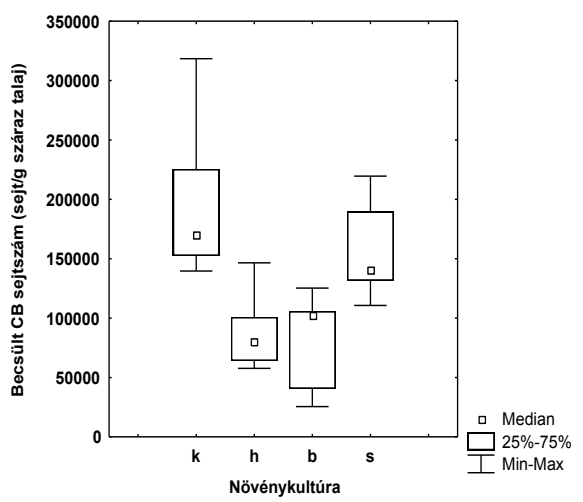

B

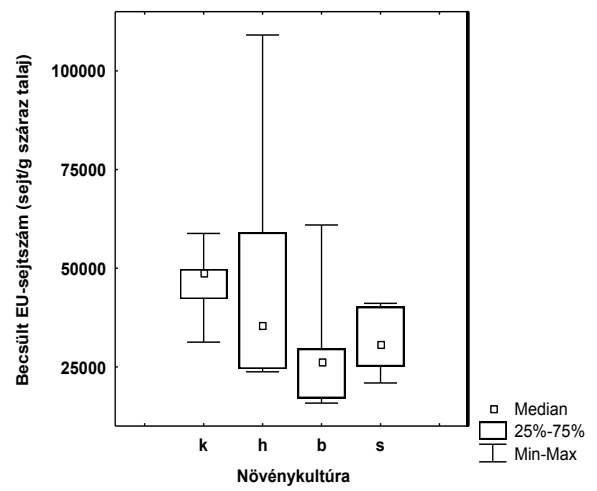

3. ábra

A becsült (A) cianobaktérium (CB) és (B) eukarióta alga (EU) sejtszámok 1g száraz talajra vonatkoztatva a kukorica $(\mathrm{k})$, a bíborhere $(\mathrm{h})$, az őszi búza (b) és a szója (s) vizsgált 0-5cm-es talajrétegében (Keszthely, $2013(\mathrm{n}=6)$ ) 


\section{Következtetések}

A bíborhere talajának nagyobb nedvességtartalmát magyarázhatja, hogy a talajminta-gyüjtés a betakarítás után egy nappal történt. Addig a növényzet teljes talajborítottságot biztosított a mintázott területen, míg a többi növénykultúránál a fedetlen sorközökböl vettük a mintákat.

Korábbi tanulmányok igazolták (SHTINA, 1969; HunT et al., 1979; SUKALA \& DAVIS, 1994), hogy lúgos kémhatású talajokban gyakoribb a cianobaktériumok előfordulása. Jelen vizsgálatban - bár valamennyi talajminta esetében a fikoeritrin tartalmú sejtcsoport képezett túlnyomó többséget, legalább 60\%-os aránnyal -, a kukorica és a szója lúgos kémhatású talajában jelentősen nagyobb cianobaktériumabundanciát és arányt mértünk. Az eredmények hasonlóságot mutatnak az azonos talajtípuson korábban végzett fluoreszcens mikroszkópos sejtszámlálási adatainkkal (LEPOSSA \& ÖRDÖG, 2006).

Jelen munka kiegészítő adatokat szolgáltat a hazai talajok alga-flórájának menynyiségére vonatkozóan. A talajvizsgálatokhoz alkalmazott áramlási citometria, hiánypótlóként, nélkülözhetetlen eszköz lehet a talajok gyors kvantitatív mikrobiológiai vizsgálatához, különös tekintettel a fotoszintetizáló szervezetekre. A talajok baktériumközösségeinek áramlási citometriás detektálásáról több közlemény is megjelent (pl. RESINA-PELFORT et al., 2003). A DNS-festékek alkalmazásával ez a sejtanalitikai technika kiterjeszthető a baktériumok egyidejű analízisére is, így további adatokat nyerhetünk a klasszikus baktériumos csíraszám vizsgálatok eredményei mellett (BIRÓ, 2006).

$\mathrm{Az}$ általunk használt áramlási citométerrel ugyanakkor a $30 \mu \mathrm{m}$-nél nagyobb méretủ sejtkolóniák, fonalak, valamint a talajszemcsék felületén biofilmet képező algák és baktériumok közvetlenül nem vizsgálhatók. WHITELEY és munkatársai (2003) szerint a módszer e hiányosságát a müszer talajalgológiai alkalmazásánál figyelembe kell venni. A minták elöszürésére azért van szükség, mert a nagyobb méretủ talajaggregátumok, algatelepek stb. a citométer eltömődését okozhatják (az általunk használt müszer gyártója a mérési tartomány felső határaként $40 \mu \mathrm{m}$ átméröt javasol - Beckman Coulter Inc. technikai információ). Speciális áramlási citométerekkel lehetséges nagyobb elemek, így algatelepek analízise is, de ezek a müszerek meglehetősen drágák, és a legtöbb egyetemi, kutatóintézeti sejtanalitikai laboratóriumban úgynevezett asztali áramlási citométerek állnak csak rendelkezésre. A módszer rutinszerủ alkalmazásának terjedése - gyorsasága és megbízhatósága miatt - a talajbiológiai vizsgálatokban is várható; amely folyamatot azonban a müszer beruházási költsége és szakember-igénye lassíthatja.

\section{Összefoglalás}

A talajokban élő cianobaktériumok és eukarióta algák edafonban betöltött szerepe kulcsfontosságú. Eddig megismert kölcsönhatásaik a talaj más szervezeteivel és a magasabb rendủ növényekkel, valamint hozzájárulásuk a talajok mikroszerkezetének kialakulásához és a nitrogénellátáshoz a legismertebbek. 
A talajalgák mennyiségi és minőségi kimutatására meglehetősen kevés közvetlen és közvetett sejtszámolási módszer és adat áll rendelkezésre.

Jelen munkánkban Ramann-féle barna erdőtalajon őszi búza, bíborhere, kukorica és szója parcellákból gyüjtött talajminták cianobaktérium- és eukarióta mikroalga sejtszám vizsgálatát végeztük el egy - ezen a téren még újnak számító - nagysebességü, automatizált sejtanalitikai módszer, az áramlási citometria alkalmazásával.

A négy növénykultúrából 2013 júliusában, Keszthelyen, a felszíni öt centiméteres talajrétegből hat ismétlésben vett talajmintákból vizes szuszpenziót készítettünk, majd mértük azok aktív algasejt-tartalmát. A cianobaktériumokat és az eukarióta algákat klorofill-a és fikoeritrin autofluoreszcencia alapján különböztettük meg a szuszpenzió egyéb elemeitől. A mérésekhez Beckman Coulter FC-500 áramlási citométert használtunk, mintánként öt perc futtatási idővel. A müszer által rögzített eseményszámból következtettünk az algasejtszám-értékekre.

A citométeres ábrákon - megfelelő beállítások után - jól elkülönülő alga sejtpopulációk jelentek meg. Valamennyi mintában a cianobaktériumok domináltak, legalább $60 \%$-os aránnyal. A kukorica talajában mutattuk ki a legnagyobb alga jelenlétet $\left(2,4 \cdot 10^{5} \mathrm{sejt} \cdot \mathrm{g}^{-1}\right.$ száraz talaj), míg a búzáéban a legkevesebbet, alig $50 \%$-ot $\left(1,1 \cdot 10^{5}\right.$ sejt $\cdot \mathrm{g}^{-1}$ száraz talaj). A cianobaktériumok becsült sejtszámát tekintve a kukorica és a szója talajában jelentősen nagyobb abundancia mutatkozott a bíborhere és őszi búza talajához viszonyítva. Szignifikáns különbséget találtunk a becsült eukarióta alga sejtszámban a kukorica- és szója talaja között, a kukorica javára.

Eredményeink igazolták, hogy az áramlási citometria megfelelő és hiánypótló módszer lehet a talajok kvantitatív mikrobiológiai vizsgálatai során, különös tekintettel a fotoszintetizáló szervezetekre.

Kulcsszavak: talaj, alga, cianobaktérium, áramlási citometria, mikrobiológia

\section{Irodalom}

BIRÓ, B., 2006. Bacterial numbers. Root dilution analysis. In: Understanding and Modelling Plant-Soil Interactions in the Rhizosphere Environment. Handbook of Methods used in Rhizosphere Research. Chapter 4.1. Microbial growth and visualization of bacteria and fungi (Eds: SchweIger, P. \& Finlay, R.) 378-379. Swiss Federal Research Institute WSL. Birmensdorf.

Chisholm, S. W., Olson, R. J., ZetTler, E. R. \& Waterbury, J., 1988. A novel freeliving prochlorophyte occurs at high cell concentrations in the oceanic euphotic zone. Nature. 334. 340-343.

FeHÉR, D., 1936. Über die Algenflora des Waldbodens. Silva. 24. (13) 101-108.

FEHÉR, D. \& FRANK, M., 1936. Untersuchungen über die Lichtökologie der Bodenalgen. Arch. Mikrobiol. 7. 1-31.

Givan, A. L., 2001. Flow Cytometry: First Principles. Second Edition. John Wiley \& Sons, Inc. New York, USA.

Hunt, M. E., Floyd, G. L. \& Stout, B. B., 1979. Soil algae in field and forest environments. Ecology. 60. (2) 362-375. 
KISS I., 1968. Vízfeltöréses („forrásos”) talajfelületek vizsgálata Dél-Alföld szikes területein, különös tekintettel a mikrovegetáció tömegprodukciós kialakulására. Szegedi Tanárképző Főiskola Tud. Közl. 3-38.

KomÁromy, Zs. P., 1976. Soil algal growth types as edaphic adaptation in Hungarian forest and grass steppe ecosystems. Acta Bot. Acad. Sci. Hung. 22. 373-379.

KomÁromy, Zs. P., 1983. A comparative study on the algal synusia of Hungarian grasslands and deciduous forests. Ann. Hist.-nat. Mus. Nat. Hung. 75. 47-53.

KomÁromy, Zs. P., 1985. The role of algal synusia of grasslands in successional processes in Hungary. Ann. Hist.-nat. Mus. Nat. Hung. 77. 97-102.

Lentendu, G., Hubschmann, T., Muller, S., Dunker, S., Buscot, F. \& Wilhelm, C., 2013. Recovery of soil unicellular eukaryotes: An efficiency and activity analysis on the single cell level. J. Microbiol. Methods. 95. 463-469.

LEPOSSA A., 2002. A talajalgákra ható ökológiai tényezők (irodalmi áttekintés). Bot. Közlem. 89. (1-2) 187-202.

LePossA, A. \& ÖRDÖG, V., 2006. Quantitative analyses of soil algae in the Balaton Upland National Park (Hungary). Agrokémia és Talajtan. 55. (1) 271-278.

Olson, R. J., VAulot, D. \& Chisholm, S. W., 1985. Marine phytoplankton distributions measured using shipboard flow cytometry. Deep Sea Res. 32. 1273-1280.

Resina-Pelfort, O., García-Junco, M., Ortega-Calvo, J. J., Comas-Riu, J. \& VIVES-REGO, J., 2003. Flow cytometry discrimination between bacteria and clayhumic acid particles during growth-linked biodegradation of phenanthrene by Pseudomonas aeruginosa 19SJ. FEMS Microbiol. Ecol. 43. (1) 55-61.

Robinson, J. P., Darzynkiewicz, Z., Dean, P. N., Orfao, A., Ribinovitch, P. S., Stewart, C. C., Tanke, H. J., Wheeless, L. L. \& Dressler, L. G. (Eds.), 1997. Current Protocols in Cytometry. Vol. 1. Wiley. New York.

ShapIRO, H. M., 1995. Applications in flow-cytometry. In: Practical Flow Cytometry. $3^{\text {rd }}$ Ed (Ed.: Shapiro, H. M.) 388-425. John Wiley \& Son. New York.

ShtinA, E. A., 1969. Über die Verbreitung und ökologische Bedeutung der Algen in Ackerböden. Pedobiologia. 9. 226-242.

SuKALA, B. L. \& DAVIS, J. S., 1994. Algae from nonfertilized soils and from soils treated with fertilizers and lime of northcentral Florida. Nova Hedwigia. 59. (1-2) 3346.

Tsujimura, S., NAKAhARA, H. \& ISHIDA, N., 2000. Estimation of soil algal biomass in salinized irrigation land: a comparison of culture dilution and chlorophyll-a extraction method. J. Appl. Phycol. 12. 1-8.

Veal, D. A., Deere, D., Ferrari, B., Piper, J. \& Attfield, P. V., 2000. Fluorescence staining and flow cytometry for monitoring microbial cells. J. Immunol. Methods. 243. 191-210.

Whiteley, A. S., Griffith, R. I. \& BAiley, M. J., 2003. Analysis of the microbial functional diversity within water-stressed soil communities by flow-cytometric analysis and CTC + cell sorting. J. Microbiol. Methods. 54. 257-267.

Érkezett: 2015. január 20. 


\title{
Direct flow cytometric analysis of cyanobacteria and eukaryotic algae from soil-water suspensions
}

\author{
${ }^{1}$ A. Lepossa, ${ }^{1}$ S. Hoffmann and ${ }^{2}$ Sz. Nagy \\ University of Pannonia, Georgikon Faculty, ${ }^{1}$ Dept. Crop Production \& Soil Science, \\ ${ }^{2}$ Dept. Animal Sciences \& Animal Husbandry, Keszthely (Hungary)
}

\begin{abstract}
Summary
Cyanobacteria and eukaryotic algae have a key role in soil ecosystems. Their interactions with other organisms in the soil and higher plants are well-known, as is their contribution to the development of the soil microstructure and to the nitrogen supply. In spite of their importance, only a few direct and indirect cell counting methods and data are available for the quantitative and qualitative detection of soil algae.

In this work we used an automatized high speed cell analysis approach, flow cytometry for the direct detection and quantitative analysis of cyanobacteria (CB) and eukaryotic microalgae (EU) from Ramann-type brown forest soil, under four crop cultures (winter wheat, crimson clover, corn and soybean) in Keszthely (Hungary). In July 2013 six individual soil samples per crop culture were collected from the top $5 \mathrm{~cm}$ soil layer. After the moisture content and $\mathrm{pH}$ of the fresh soil samples were measured, $10 \mathrm{~g} \cdot$ $100 \mathrm{ml}$ aqueous suspensions were prepared and filtered $(30 \mu \mathrm{m})$ before the active algal cell contents were measured. Cyanobacteria and eukaryotic algae were distinguished from each other and from the other components of the soil suspension on the basis of chlorophyll-a and phycoerythrin autofluorescence. Measurements were performed with a Beckman Coulter FC 500 flow cytometer and the data files were analyzed with the Flowing 2.5.1 free software. Kruskal-Wallis ANOVA and post hoc Mann-Whitney Utest were used for statistical analysis using Statistica for Windows 8.0 software.

The cytograms showed distinct cell populations. The soil moisture contents varied between 5.1-6.3\% with the exception of crimson clover, where the value was $10.1 \%$ due to the better surface coverage of this crop. Soil $\mathrm{pH}_{\mathrm{H} 2 \mathrm{O}}$ varied between 6.7 and 8.6. Algal cell numbers were calculated in terms of $1 \mathrm{~g}$ dry soil from the events detected by the flow cytometer, and corrected with the soil moisture contents. Cyanobacteria were dominant in all the samples making up at least $60 \%$ of the total algal cell numbers. Soil samples under maize showed the highest algae presence $\left(2.4 \cdot 10^{5}\right.$ cells/g dry soil), and wheat soil the lowest, less than $50 \%$ of that measured for maize soil. The estimated numbers of cyanobacteria were significantly higher in maize and soybean soil than in crimson clover and winter wheat soils. Significant $(p<0.05)$ differences between the estimated eukaryotic algal cell numbers could only be detected between the maize and soybean soils, in favor of maize.

The results indicated that flow cytometry may be appropriate tool for quantitative microbiological tests, particularly from the point of view of photosynthetic participants in the soil microflora.

Fig. 1. Detected colonies of cyanobacteria (rounded area) and eukaryotic algae (marked with arrow) in the cytograms recorded for aqueous suspensions of the soils under maize, crimson clover, winter wheat and soybean.
\end{abstract}


Fig. 2. Estimated average total algal cell numbers with the ratio of cyanobacteria (CB) and eukaryotic (EU) algae in the $0-5 \mathrm{~cm}$ soil layer under crops ofmaize (k), crimson clover (h), winter wheat (b) and soybean (s), Keszthely (Hungary), $2013(\mathrm{n}=6)$.

Fig. 3. Estimated (A) cyanobacterial - CB; (B) eukaryotic algal cell numbers in terms of $1 \mathrm{~g}$ dry soil, in the $0-5 \mathrm{~cm}$ soil layer under maize $(\mathrm{k})$, crimson clover $(\mathrm{h})$, winter wheat (b) and soybean (s), Keszthely (Hungary), $2013(\mathrm{n}=6)$. 